\title{
Position of Prague on The International Tourism Market
}

\author{
Jiri Vanicek \\ University of Economy Prague, Czech Republic
}

\begin{abstract}
There are not many European countries with such a significant share of the capital city on tourism (especially incoming tourism) as the Czech Republic. The number of foreign tourists grows significantly in the Czech Republic, and so does the share of Prague. All marketing campaigns aiming to get foreign tourists beyond Prague ended inefficient. The share of Prague on the number of tourists accommodated in standard accommodation facilities on the total number of tourists in the Czech Republic (CZ) is $62 \%$. Prague is also the only region with a higher number of foreign tourists than Czech tourists ( $85 \%$ of tourists in Prague are foreigners). Prague is therefore struggling with overtourism in some attractive areas and must deal with unsustainable development.
\end{abstract}

Keywords: Benchmarking, City tourism, Overtourism, Prague, Urban tourism

\section{Introduction}

The number of tourists has grown for seven years in a row in the Czech Republic (Čsú, 2019d). Even though the CzechTourism agency has been working on diversification in communication and spreading of awareness of the beauty of other regions in the Czech Republic, most tourists are still headed to Prague. Some areas (main tourist attractions) are visited by excessive numbers of tourists that reach limits of sustainability. Therefore, it can be perceived as the problem of so-called overtourism, i.e. overload of tourists in small areas/destinations. Authors follow on their own research that compares attendances in Prague and other cities. High concentration of tourists in one area (i.e. overtourism) causes a number of problems - from starting with worse conditions for residents, via increased prices of goods/services and ending with damage to environment and cultural heritage. In order to improve overtourism management, it is necessary to examine in detail its roots and prepare preventative and corrective measures. The article introduces results of primary and secondary research that aims to evaluate the position of Prague in the context of tourism in the Czech Republic and to find possible causes of excessive concentration of tourists in one area/destination. Historical sites and culture have always been the main motivation for traveling and tourism. They are the main motivation for $36 \%$ of tourists, more precisely $41 \%$ of foreign tourists in the Czech Republic (CzechTourism, 2018 a). It is therefore undeniable that (not only) capital cities are highly attractive - looking from the historical perspective, they have always been the most important, and therefore, the number of places with architectural/historical value is significantly higher as compared to other cities. Smaller European cities obviously cannot compete with their sights. A study of the European Parliament (Peeters et al., 2018) uses the annual number of tourists per 100 inhabitants and per $1 \mathrm{~km}^{2}$ for the evaluation of overtourism. Results show clear differences between rural, urban, coastal/islands and heritage/attractions tourism. According to the study, overtourism has impact on the environment (pollution, damage, investment in wrong projects), economy (inflation, economic dependence on tourism, infrastructure costs) and culture (degradation of conditions for residents, conflicts, criminality, loss of identity). Preveden points out in his study that most problems arise from lack of destination planning to prevent overtourism. Most destinations focus on attracting as many tourists as possible, but they do not 
consider consequences. Preveden therefore offers proactive and reactive measures.

Destinations should proactively align tourism strategy with city development strategy; they should build infrastructure also in low-tourism areas; improve segmentation and target various segments across seasons. Reactive measures work with regulation of capacities of accommodation facilities, active management of sharing economy and restrictions on access to selected areas: entry tickets, dynamic pricing according to the time/season, maximum number of visitors etc. (Preveden et al., 2018). Furthermore, Jordan (Jordan et al., 2018) includes public education, better on-the-ground tourist management, technological solutions or better monitoring in tools for overtourism management. One of the trends of international tourism is dynamic growth of popularity and number of visitors in global and European metropolises in the last years. This fact is illustrated by figure 1 . The lowest share of residents is in Venice $(11 \%)$, Prague (14\%) and Amsterdam (18\%). Data of the Czech Statistical Office (Čsú) for Prague are slightly different, but data from one source were used in order to keep the comparison valid.

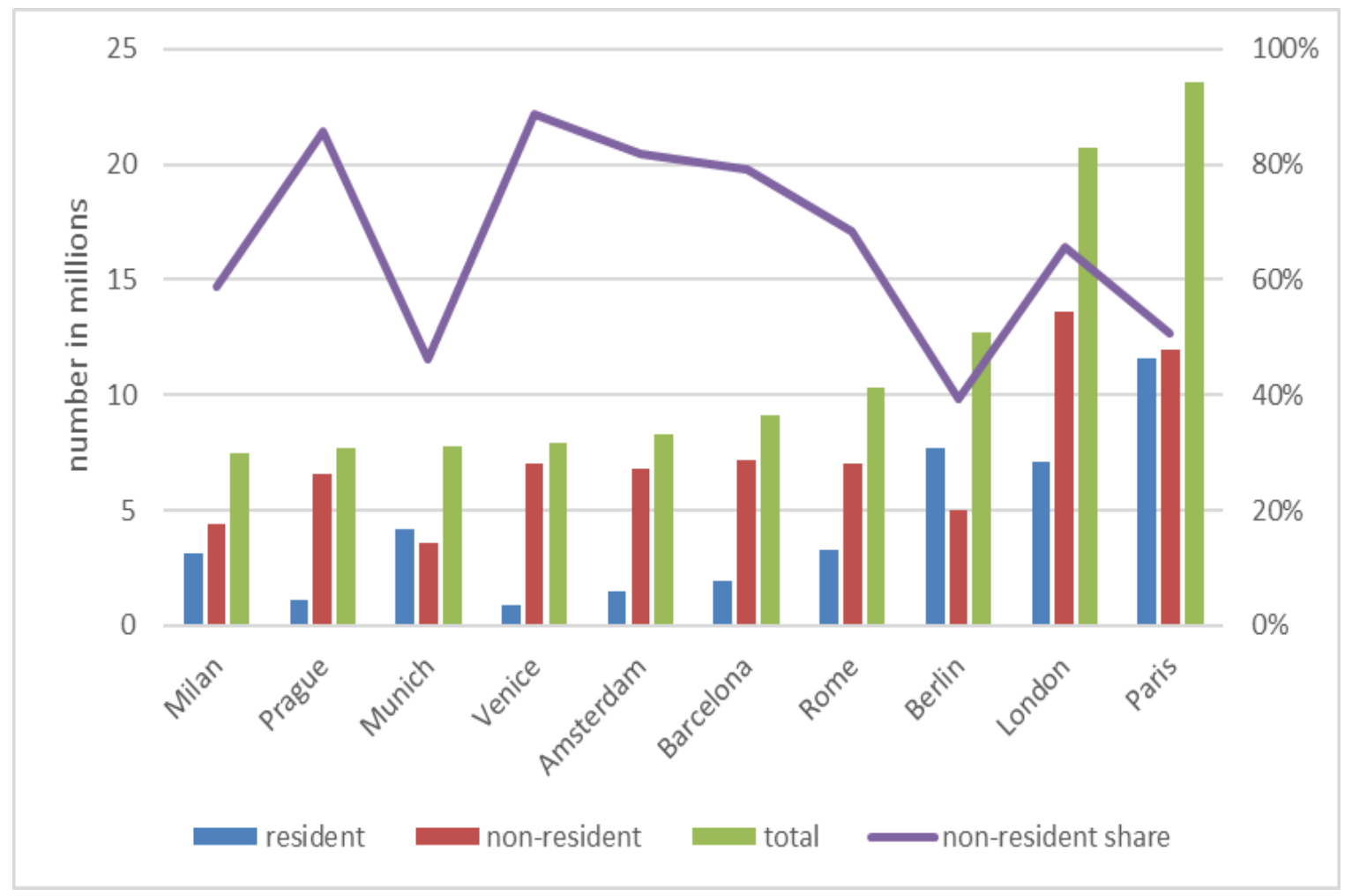

Figure 1: The most visited cities in Europe in 2017

Source: TourMIS 2018, ISTAT 2018 - edited by authors

\section{Urban Tourism in The Czech Republic}

Incoming tourism in the Czech Republic reached the new maximum of number of tourists and overnight stays in 2018. Majority (62\%) of foreign tourists went to Prague. The number of tourists in Prague was 7.9 million out of which 6.7 million $(85 \%)$ were guests from abroad in 2018 (PCT, 2018d). The Top 100 Cities Destination Ranking Euromonitor International ranks Prague to fifth/sixth position among European cities in the number of arrivals in 2012-2017 (PCT, 2018b). Prague took the seventh place among 126 evaluated European cities with total 18 million overnight stays in 2017 (PCT, 2018c). There are eight other cities with over 100,000 inhabitants in the Czech Republic (Brno, Ostrava, Pilsen, Liberec, Olomouc, Ústí nad Labem, Hradec Králové, České Budějovice). They are all country towns. They have important attractions 
Jiri Vanicek

Position of Prague on The International Tourism Market

and an interesting offer for visitors; however, their number of tourists is not as high as in the capital city.

Table 1: Comparison of the number of tourists in the most important Czech cities in 2017

\begin{tabular}{|c|c|c|c|c|c|c|}
\hline & \multicolumn{3}{|c|}{$\begin{array}{l}\text { Number of guests in accommodation } \\
\text { establishments }\end{array}$} & \multicolumn{3}{|c|}{ Number of overnight stays } \\
\hline & Czech & Foreigners & STotal & Czech & Foreigners & sTotal \\
\hline \multirow{2}{*}{ Prague } & $1,090,000$ & $6,562,000$ & \multirow{2}{*}{$7,652,000$} & $1,923,000$ & $16,132,000$ & \multirow{2}{*}{$18,055,000$} \\
\hline & $14 \%$ & $86 \%$ & & $11 \%$ & $89 \%$ & \\
\hline \multirow{2}{*}{ Pilsen } & 125,000 & 167,000 & \multirow{2}{*}{292,000} & 205,000 & 306,000 & \multirow{2}{*}{511,000} \\
\hline & $43 \%$ & $57 \%$ & & $40 \%$ & $60 \%$ & \\
\hline \multirow{2}{*}{ Brno } & 334,000 & 388,000 & \multirow{2}{*}{722,000} & 577,000 & 689,000 & \multirow{2}{*}{$1,266,000$} \\
\hline & $46 \%$ & $54 \%$ & & $46 \%$ & $54 \%$ & \\
\hline \multirow{2}{*}{ Karlovy Vary } & 184,000 & 321,000 & \multirow{2}{*}{505,000} & 732,000 & \multirow{2}{*}{\multicolumn{2}{|c|}{${ }_{70 \%}^{1,734,000} 2,466,000$}} \\
\hline & $36 \%$ & $64 \%$ & & $30 \%$ & & \\
\hline
\end{tabular}

Source: Czech Statistical Office data for 2017 - edited by authors Čsú, 2019a, Čsú, 2019d

Data in table 1 clearly prove the dominance of Prague as the most attractive city in the country. The extraordinary position of Prague in incoming tourism in the Czech Republic is given by several factors:

- Prague has exceptional culturally historical conditions: Historical core of the city is globally the biggest urban conservation area with extant authentic buildings from $10^{\text {th }}-21^{\text {st }}$ century that captures historical development of the city. The historical core is on the World Heritage List of UNESCO since 1992. The location of the city at a sloping shore of meander of the VItava river creates a picturesque scene.

- Prague has an image of interesting destination and it has stronger brand than the whole Czech Republic.

- Prague is attractive also thanks to the image of a safe destination.

- Accessibility of Prague is the easiest within the Czech Republic: Václav Havel International Airport is one of the fastest growing airports in its category in Europe -16,797,006 travellers in 2018 (year-on-year growth of 9\%) (PCT, 2018a), international train and bus connections and great accessibility by individual road network.

- Tourism infrastructure (accommodation and restaurants) has high capacity and varied structure.

- A wide range of complimentary services.

- Quality products' offer for visitors, especially for cultural tourism.

- Significant part of tourism in Prague is constituted by business tourism - Prague has quality congress centres - there are over 100 big international congresses and further 4,500 smaller conferences in Prague every year (Čsú, 2019c).

Tourists usually use three routes when they visit the historical area in the Prague city centre. The longest is the Royal Route, that goes from the Powder Tower to the Prague Castle (approx.

$2.7 \mathrm{~km}$ ), the second is the route from Strahov Monastery via Prague Castle to Klárov (approx. $2 \mathrm{~km}$ ) and third route goes via Jewish Quarter starting at the Old Town Square through Maiselova street to the Old New Synagogue (approx. 700 m). Most Prague's visitors start their sightseeing 
Jiri Vanicek

Position of Prague on The International Tourism Market

tour of the historical core in the morning (around 9-11 am) at the Prague Castle and then follow through the historical centre for three kilometres to the Old Town Square. Prague's narrow streets therefore must accommodate a crowd of 30-60 thousand people per day in the season. This creates high concentration of visitors in peak hours on a very small area. The number of visitors of individual sights is only an indicative number, since most Prague's visitors look at sights from the exterior. According to the number of sold tickets, the Prague Castle was visited by 2.4 million people, but total number of visitors (passing through the site) is estimated to eight million - that is 3.3 times more visitors (data for 2017, PCT 2018e). The same number of tourists visit the Old Town Square and Charles Bridge. Similar situation is at the Jewish Quarter - the Jewish Museum has 716 thousand visitors, but the number of people passing through is significantly higher. The problem is therefore not the total number of visitors, but their uneven distribution in time and geographical space. It causes high concentration of people in a limited time on a small area of Prague. Residents are not irritated by the total number of visitors, but they complain on breach of the quiet hours in areas with night clubs and vandalism done by some groups of visitors.

\section{Research Results}

In order to prove the unique position of Prague, several factors were compared in the following tables (no. 2-7). The most attractive European destination is London with almost 21 million tourists in 2018. Three more cities were chosen for better comparison (table 2) of data: Paris, Rome and Prague (GEERTS, 2018). Data from Geerts were used in order to provide relevant comparison, since the data of the Czech Statistical Office show different numbers for Prague. The share of the Czech capital city is the highest in the number of foreign tourists. Number of tourists per one inhabitant is comparable with Paris.

Table 2: Comparison of tourism intensity in four European metropolises in 2018

\begin{tabular}{|c|llllll|}
\hline City & $\begin{array}{l}1 \\
\text { Country }\end{array}$ & $\begin{array}{l}\text { Number } \\
\text { tourists } \\
\text { metropolis }\end{array}$ & $\begin{array}{l}\text { ofNumber } \\
\text { intourists } \\
\text { country }\end{array}$ & $\begin{array}{l}\text { ofNumber of } \\
\text { ininhabitants intourists in } \\
\text { metropolis }\end{array}$ & $\begin{array}{l}\text { Number of } \\
\text { metropolis }\end{array}$ & $\begin{array}{l}\text { tourists per } 1 \\
\text { inhabitant }\end{array}$ \\
& in million & in million & in million & in \% & $\begin{array}{l}\text { tourist/inhabita } \\
\text { nt }\end{array}$ \\
\hline LondonGB & 20.8 & 39.2 & 8.8 & 53.0 & 2.4 \\
\hline Paris F & 16.8 & 87.0 & 2.2 & 19.3 & 7.6 \\
\hline RomeI & 9.7 & 42.0 & 2.9 & 23.0 & 3.3 \\
\hline PragueCZ & 9.0 & 12.8 & 1.3 & 70.3 & 6.9 \\
\hline
\end{tabular}

Source: GEERTS 2018 - edited by authors

Table 3 shows number of tourists in Prague in comparison with the whole country. Czech Statistical Office (Čsú, 2019a) monitors number of accommodated tourists in standard accommodation establishments. All data are therefore comparable for all regions of the Czech Republic. Around $37 \%$ of all tourists are accommodated in Prague - focused on foreigners it is $63 \%$ of tourists. Only $11 \%$ of Czech tourists are accommodated in Prague, since domestic tourists find prices in Prague too high and rather visit Prague only for one day or find accommodation outside Prague and commute daily. The share of Prague in year-on-year growth of tourist in the Czech Republic was 55\%. 
Jiri Vanicek

Position of Prague on The International Tourism Market

Table 3: Comparison of tourism intensity in Prague and the rest of the Czech Republic in 2018

\begin{tabular}{|lllll|}
\hline & $\begin{array}{l}\text { Number of tourists in } \\
\text { thousands }\end{array}$ & $\begin{array}{l}\text { Foreigners in } \\
\text { thousands }\end{array}$ & $\begin{array}{l}\text { Residents in } \\
\text { thousands }\end{array}$ & $\begin{array}{l}\text { Year-on-year } \\
\text { growth }\end{array}$ \\
\hline Prague & 7,895 & 6,674 & 1.221 & $12.0 \%$ \\
CZ without Prague & 13,380 & 3,965 & 9415 & $6.2 \%$ \\
\hline Czech Republic total & 21,275 & 10,639 & 10,636 & $8.1 \%$ \\
\hline Share of Prague & $37.1 \%$ & $62.7 \%$ & $11.5 \%$ & $55 \%$ \\
\hline
\end{tabular}

Source: Czech Statistical Office - edited by authors ČSÚ, 2019a

Table 4 provides data on accommodation capacity in the Czech Republic. The number of hotels and boarding houses in Prague makes almost 9\% of the total number in the Czech Republic. Those facilities are usually bigger - the number of rooms constitute one fifth of the total number in the country.

The number of beds is slightly lower, since there are more single rooms in Prague. Nevertheless, Prague has the highest occupancy (67\%) compared to the rest of the country (50\%) (Čsú, 2019 e).

Table 4: Prague's share on accommodation capacity in the Czech Republic in 2018

\begin{tabular}{|l|lll|l|}
\hline & $\begin{array}{c}\text { Number of } \\
\text { Establishments }\end{array}$ & $\begin{array}{l}\text { umber of } \\
\text { Rooms }\end{array}$ & mber of Beds & Use of beds \\
\hline Czech Republic & 9,007 & 205,324 & 526,788 & $49.9 \%$ \\
\hline Prague & 787 & 41,617 & 90,891 & $67.0 \%$ \\
\hline Share of Prague & $8.7 \%$ & $20.3 \%$ & $17.3 \%$ & $34 \%$ \\
\hline
\end{tabular}

Source: Czech Statistical Office - edited by authors Čsú, 2019 b

The structure of accommodation establishments by classification (quality) is also significantly better in Prague than in the rest of the country. Three quarters of all five-star hotels and one third of four-star hotels are in Prague. On the other hand, only every $37^{\text {th }}$ boarding house is in Prague. Specific data is given in table 5 .

Table 5: Prague's share on accommodation capacity by classification in 2018

\begin{tabular}{|c|c|c|c|c|c|}
\hline & $\begin{array}{l}\text { Hotels } \\
* * * * *\end{array}$ & $\begin{array}{l}\text { Hotels } \\
* * * *\end{array}$ & $\begin{array}{l}\text { Hotels } \\
* * *\end{array}$ & $\begin{array}{l}\text { 3oarding } \\
\text { Houses }\end{array}$ & Hotel Garni \\
\hline Czech Republic & & 653 & 1,385 & 3,427 & 111 \\
\hline Prague & 46 & 218 & 210 & 94 & 34 \\
\hline $\begin{array}{l}\text { Share of } \\
\text { Prague }\end{array}$ & $75.4 \%$ & $33.4 \%$ & $15.2 \%$ & $2.7 \%$ & $30.6 \%$ \\
\hline
\end{tabular}

Source: Czech Statistical Office - edited by authors Čsú, 2019b 
Jiri Vanicek

Position of Prague on The International Tourism Market

Table 6 shows ten most visited tourist attractions in the Czech Republic. It is obvious, that six out of them are in Prague and that four are ZOOs.

Table 6: Ten most visited tourist attractions in the Czech Republic in 2017 (in thousand)

\begin{tabular}{|lll|}
\hline Tourist attraction & City & Number of visitors (in thousand) \\
\hline Prague Castle & Prague & 2,378 \\
\hline Petř́n Cable Car & Prague & 2,066 \\
\hline Prague ZOO & Prague & 1,446 \\
\hline AquaPalace Prague & Prague & 836 \\
\hline Aqualand Moravia & Pasohlávky & 721 \\
\hline Petř́n Lookout Tower & Prague & 714 \\
Pinkas Synagogue & Prague & 675 \\
ZOO Zlín-Lešná & Zlín & 630 \\
ZOO Dvůr Králové n/Labem & Dvưr Králové nad Labem & 525 \\
ZOO Ostrava & Ostrava & 507
\end{tabular}

Source: Czech Statistical Office - edited by authors (CzechTourism 2018 b)

The above-mentioned data show that the situation in Prague is unique and deserves attention of experts. Current tourist/resident ratio and density of tourists are clearly unsustainable.

\section{Conclusion and Discussion}

Despite the effort of destination managements including the CzechTourism agency, the number of tourists in Prague is several times higher than in the rest of the country. Prague is easily accessible for tourists from distant countries, it has reputation of a safe city, it is considered cheap, and thanks to its location in the heart of Europe, it is a good starting point for exploring trips around Europe. Data of the CzechTourism (2018a) agency show, that 31\% of foreign tourists arrive in the Czech Republic by airplane and $45 \%$ arrive by car. Considering the quality of road infrastructure (ex. highway to Brno, or to Moravia) it is obvious that tourist do not want to travel beyond Prague. The data also show that $52 \%$ of tourists are in Prague for the first time - trips out of Prague are therefore more likely to happen during their next visits. That is also related to the motivation of tourists coming to the Czech Republic especially for cultural sight (59\% of respondents). High concentration of cultural sights in Prague is reflected in high concentration of tourists (PCT $2018 \mathrm{~d}$ ). Problems arise from high concentration of tourists in few areas - only some places in Prague are overcrowded and suffer from negative effects of overtourism. Better flow of tourists in Prague could be arranged by better tourist direction signs, higher awareness about alternative routes and general education of tourists and residents on negative effects of excessive attendance. In order to protect some sights, it would be beneficial to launch daily quotas for maximum number of visitors, alternatively decrease entrance fee in less exposed times/seasons, or to offer attractive accompanying program. Increased costs for repairs of damage caused by overtourism might be partially compensated by increased spa and recreational fee. Overtourism is a problem of modern society - it is a result of luxury lifestyle we have. Travelling is accessible to more and more people, and therefore the number of visitors in (capital) cities increases. The Ministry for Regional Development should cooperate with the CzechTourism agency and reconsider the strategy of cities' development together with the importance of tourism for the whole ecosystem of the Czech Republic. The number of tourists in Prague will most likely continue increasing, however it is necessary to prepare a plan for remedial action and detailed plan to prevent future negative effects. The strategy of constant growth of tourism is rooted in the history of many cities, but its consequences are not considered. Capacity of tourist destinations is limited just as the capacity of means of transport or accommodation establishments. Even though everyone is trying to maximize profit, it is not 
Jiri Vanicek

Position of Prague on The International Tourism Market

always in the interest of inhabitants, environment, historical sites or tourists themselves. Overtourism, or excessive concentration of tourists in a destination, endangers several cities across Europe - and Prague, precisely its historical core, is one of them.

\section{References}

- Airdna.co, 2019: Short-term rental data \& analytics. Retrieved 24.03.2019 from: https://www.airdna.co/

- Čsú [Český statistický úřad], 2019a: Hosté v hromadných ubytovacích zařizeních podle krajů v roce 2018, Retrieved 24.03.2019 from: https://www.czso.cz/csu/xk/navstevnost-vkarlovarskem-kraji-v-roce-2018

- Čsú [Český statistický úřad], 2019b: Kapacity hromadných ubytovacích zařízení podle kategorie. Retrieved 23.03.2019 from: https://vdb.czso.cz/vdbvo2/faces/cs/index.jsf

- ?page $=$ vystup-objekt-parametry\&sp $=A \& p v o k c=\& k a t a l o g=31742 \& p v o=C R U 01 \& z=T$

- Čsú [Český statistický úřad], 2019c: Konference v hromadných ubytovacích zařízeních, Retrieved 23.03.2019 from: https://vdb.czso.cz/vdbvo2/faces/cs/index.jsf?page=vystupobjekt\&pvo $=$ CRU07a\& $z=T \& f=T A B U L K A \&$ skupId $=1270 \&$ katalog $=31743 \& p v o=C R U 0$ $7 a \& s t r=v 77 \& c=v 3 \sim 8$ RP2018 (Vygenerováno 14.04.2019 10:02:24)

- Čsú [Český statistický úřad], 2019d: Hosté a přenocování v hromadných ubytovacích zařízeních Retrieved 17.04.2019 from: https://vdb.czso.cz/vdbvo2/faces/cs/index.jsf?page

- =vystup-objekt\&pvo=CRU03\&skupId $=1330 \& z=T \& f=T A B U L K A \& k a t a l o g=31743 \& p v o$

- $=$ CRU03\&str $=\mathrm{v} 282$

- CzechTourism, 2018 b: Návštěvnost turistických cílů 2017. Retrieved 17.04.2019 from https://czechtourism.cz/getattachment/Pro-media/Tiskove-zpravy/Navstevnost-turistickyc h-cilu-v-CR-lakaji-historic/Czech_Tourism_nej_turisticke_cile.pdf.aspx?ext=.pdf 